\title{
The Effect of Green Harvest on the Quality of Organic Grapes Cultivated in Murfatlar Viticultural Centre
}

\author{
Victoria ARTEM ${ }^{1,2}$, Arina Oana ANTOCE ${ }^{1 *}$, Ioan NAMOLOSANU ${ }^{1}$, Aurora RANCA ${ }^{2}$, Anamaria \\ PETRESCU ${ }^{1,2}$ \\ ${ }^{1}$ University of Agronomical Sciences and Veterinary Medicine of Bucharest, Faculty of Horticulture, \\ Department of Bioengineering of Horti-Viticultural Systems, 59, Mărăşti Ave., Sector 1, 011464 Bucharest, \\ Romania. \\ ${ }^{2}$ Research Station for Viticulture and Oenology Murfatlar, Calea Bucuresti str., no. 2, 905100, Murfatlar, \\ Constanta \\ *)corresponding author, e-mail: arina.antoce@horticultura-bucuresti.ro
}

BulletinUASVM Horticulture 72(2) / 2015

Print ISSN 1843-5254, Electronic ISSN 1843-5394

DOI:10.15835/buasvmen-hort:11360

\begin{abstract}
In viticulture, the control of the crop load is largely used as an important instrument for the regulation of yield and grape quality, which in turn leads to quality wines. One of the practices for the regulation of crop load, often used for table grapes, is the green harvest, that is, the removal of some unripe bunches in order to drive more of the vines' strength towards the remaining clusters. At present this practice is also applied for wine grapes, regulating in this way the yield and the quality of grapes and wines, due to a better accumulation of sugar in the berries of the remaining bunches and a better accumulation of aromatic and colour compounds into the grape skins. In this paper we present the results regarding the usability and agro-biological behaviour to green harvesting of two vine cultivars (Feteasca Neagra and Cabernet Sauvignon) grown in organic plantations in Murfatlar vine region, as compared to controls without cluster thinning. The main parameters followed were the indicators of grape quality (sugar concentration, total acidity, $\mathrm{pH}$, anthocyanins and total polyphenolic index) and the technological parameters (the average weight of the cluster, the weight and number of the berries, the rachis weight and the yield per vine). The statistical analysis of the results showed that the green harvest had a beneficial effect on the grape composition and wine quality for both varieties.
\end{abstract}

Keywords: cluster thinning, organic, quality grapes.

\section{INTRODUCTION}

In order to obtain quality wines of premium level it is necessary to find solutions in the vineyard to raise the grape quality. In this regard various agronomic practices can be used, such summer pruning and clusters thinning, which influence the ripening and some parameters of berries, such as the sugar content, $\mathrm{pH}$, total acidity, flavor and color (Demir, 2011).

Thus, the cluster thinning has a direct effect on the relationship between nutrient supply and vine requirements, which means that with fewer grape clusters on a vine the photosynthetic assimilation is improved, leading to an increase in the quality of grapes (Reynolds et al., 1994).
In addition, these operations improve the plant health, because the vine is better ventilated, while the leaves and clusters get more light and air. Some researchers have found that the most effective time for thinning is in the phenological phase of grape ripening (Jackson et al., 1993; Bubola et al., 2011). The influence of thinning on $\mathrm{pH}$ and total acidity is less important than in the case of sugar accumulation. In previous studies, some authors have found a higher content of anthocyanins and polyphenols in the case of an increased foliage/ grape ratio due to thinning (Filippetti et al., 2007). The clusters thinning practice is applied to adjust the level of nutrient usage efficiency, being especially beneficial during unfavorable ripening 
climatic conditions or when the number of grapes exceeds the recommended yield (Valdes et al., 2009). However, although some reports in the literature showed positive results (Merchán et al., 2011), by applying these operations, in some other cases, no clear effect was demonstrated (Guidoni et al., 2008).

The concept that dominates this century is "the return to nature", which implies to avoid or to use as little as possible synthetic chemical compounds in both agriculture and food industry. In recent years the focus is on organic agriculture, which aims to obtain food products without the use of synthetic organic products (pesticides, fertilizers, stimulators, growth regulators, antibiotics etc.). Organic farming differs fundamentally from other agricultural systems, as finished products can not be sold under the name "organic" only if they are not approved by an authorized organism. Obtaining the ecological certificate involves obeying several legal rules and going through several stages, before applying for inspection and certification (Antoce et al., 2008).

At the Research Center for Viticulture and Oenology Murfatlar some grape varieties are organically grown since 2007. Currently, 45 ha of vineyards are registered as organically grown, of which 15 hectares are certified and 30 ha are in conversion. The varieties grown in this system are Columna and Chardonnay for white wines and Feteasca Neagra, Cabernet Sauvignon and Pinot Noir for red wines (Ranca et al., 2013). The total certified organic surface with Cabernet Sauvignon and Feteasca Neagra varieties is 12.4 ha.

\section{MATERIALS AND METHODS}

This study aimed to assess in Murfatlar vineyard ecosystem the agrobiological suitability for ecological production and the behavior of two wine varieties organically grown (Feteasca Negra and Cabernet Sauvignon), by using standardized loads/per vine obtained by cluster thinning. Vines with no standardized load (no cluster thinning) were used as references. Results recorded for technological and quality parameters of grapes and wines obtained in the experimental variants represent the averages of two consecutive years (2013 and 2014). The two experimental plots studied are young plantations, the one with Feteasca Neagra being planted in 2007 and the other, with Cabernet Sauvignon, in 2009; the first one was certified for organic production after undergoing a conversion period of three years, by the authorizing organism ICEA Romania (an entity mandated by the Ministry of Agriculture and Rural Development of Romania). The land has an N-S exhibition with a slope of 3-5\%, soil type is calcareous chernozem with clayey texture. The training system is spur-pruned bilateral cordon on mid-stem (70 cm hight), rootstock is Berlandieri $\mathrm{x}$ Riparia Oppenheim 4 S04-4 clone, while the planting distance is of $2.2 \mathrm{~m}$ between rows and $1.1 \mathrm{~m}$ between vines, with an initial density of 4132 vines/ha. The experimental design included blocks for two variants with three repetitions for each of the two studied varieties. All applied operations respected the technological steps and rules for an ecological culture system, as imposed by the Regulation (EC) No 834/2007 concerning organic production and labeling (Council Regulation (EEC) $N^{\circ}$ 834/2007). Sugar content was determined using Smart electronic refractometer produced by Atago, Japan; total acidity was determined titrimetrically with 0.1 $\mathrm{N} \mathrm{NaOH}$ solution; berries weight was measured with technical balance, reporting the mass for 100 berries; total anthocyanins content and total polyphenol index were determined by the method ITV, developed by the Institut Français de la Vigne et du Vin (http://www.vignevin-sudouest.com). Mechanical composition of grapes expressed by gravimetric and numerical ratios between several uvological units, such as grape rachis, skin grape, pulp and seeds. The following indicators are calculated: the grape structure index, berries index, the berry composition index and yield index. Winemaking was performed in batches of $50 \mathrm{~kg}$ in the microvinification compartment, by applying the classic technology for obtaining quality dry red wines, including fermentation and maceration on skins, without added yeasts, yeasts nutrients or enzymes.

Physico-chemical composition of the wines was evaluated based on the overall composition parameters (alcohol, total and volatile acidity, reducing sugar, total dry extract and nonreducing dry extract) according to specific literature and international methods or national standards. The composition of polyphenols (anthocyanins and other classes of polyphenols), was performed by spectrophotometric methods using UV-VIS spectrophotometer Helios Alpha, 
product of ThermoScientific, USA. The content in anthocyanins (mg/l) was determined by the method Ribereau Gayón-Stonestreet, based on the color change depending on $\mathrm{pH}$ anthocyanins, measuring the $520 \mathrm{~nm}$ absorbance variation in the color of anthocyanins at pH 0.6 to 3.5 against distilled water, (Ribereau Gayon et al., 1976). Total polyphenols (mg GAE/l), were determined by the method of Singleton-Rossi, based on the ability of the wine phenolic compounds to get oxidized with the Folin-Ciocalteau reagent. The resulting blue color has a maximum absorbance at $675 \mathrm{~nm}$, the absorbance being proportional to the amount of wine phenolic compounds (Singleton et al., 1965). Wine color intensity and hue was evaluated as stated by Glories (1984), measuring the optical density at 420, 520 and $620 \mathrm{~nm}$ using an UV/VIS spectrophotometer (Thermo Scientific, USA) and the results are expressed as percentage of color contribution of yellow, red and blue on the total color of wine. Statistical analysis was performed using the XLSTAT (Addinsoft) software. For the paired samples t-test was used the significance level value was chosen $\mathrm{p} \leq 0.05$.

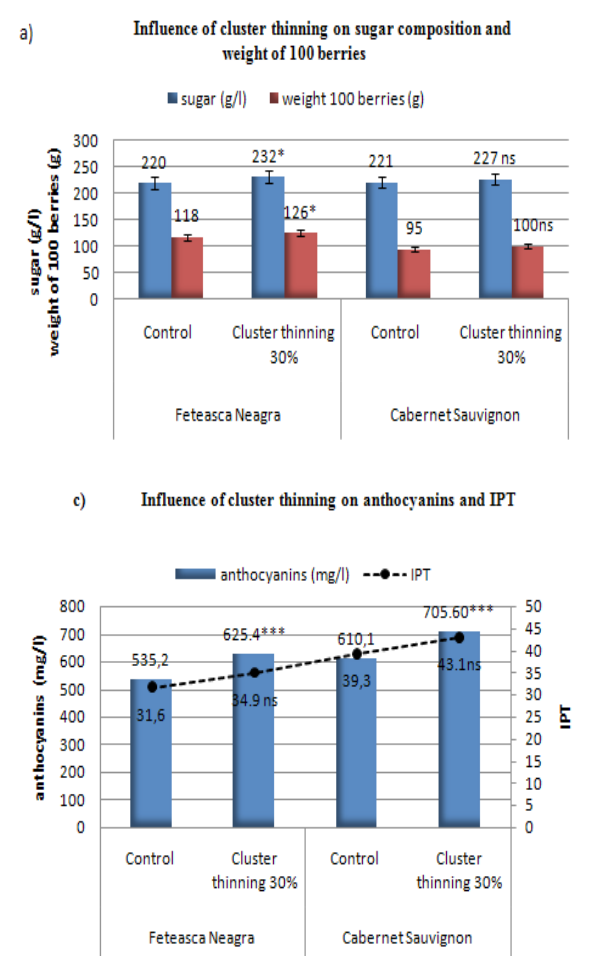

\section{RESULTS AND DISCUSSION}

Among the grape compounds, sugars, acids and the phenolic substances are the most important elements for wine quality. The influence of ecological factors on the accumulation of sugars in the grapes is very complex and behaves differently from one variety to another, from one cultural system to another and, of course, from one technology to another.

By statistically analyzing pairs the obtained data shown in Fig. 1, we find that, thinning of clusters operation led to a significant increase in sugar content, with $5.4 \%$ and weight of 100 berries with $6.7 \%$ for Feteasca Neagra. For Cabernet Sauvignon, thinning of clusters operation led to a insignificant increase in sugar content and weight of 100 berries. Organic acids and sugars are the basic chemical components of the grapes, they contributing not only to the perception of the sour and sweet taste but also to the mouthfeel and balance of wines.

From Fig. 1b it can be observed that the acidity is reduced significant in the case of $30 \%$ clusters thinning, an expected phenomenon due to the inverse correlation with the increase of reducing

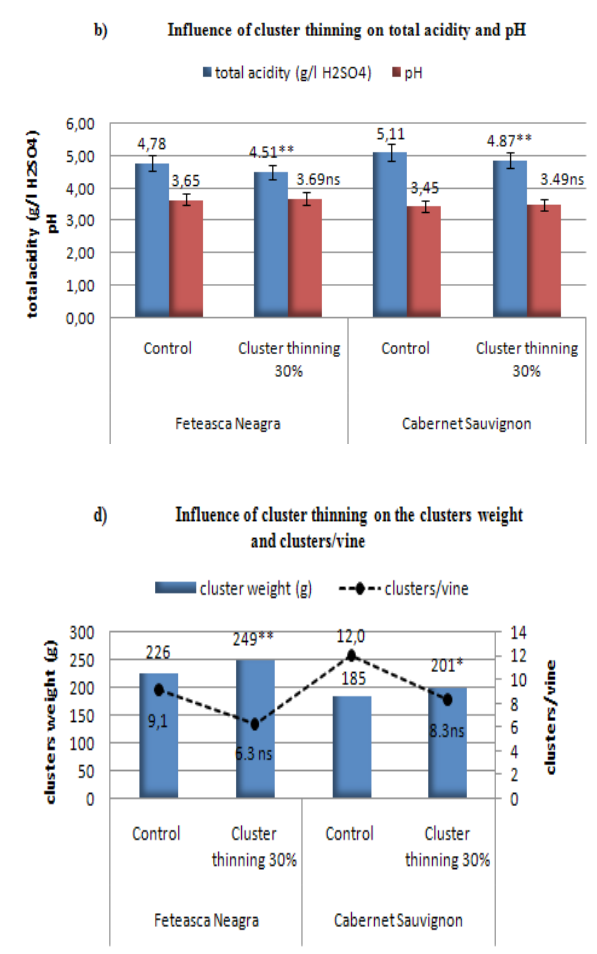

Fig. 1. The influence of clusters thinning per vine on quality parameter (ns, ${ }^{* * *, * * *}$ indicate nonsignificance and significance at $\mathrm{p} \leq 0.05, \mathrm{p} \leq 0.01, \mathrm{p} \leq 0.001$ respectively) 
Tab. 1. The grape parameters, indices and yield at harvest

\begin{tabular}{|c|c|c|c|c|c|c|}
\hline \multirow[b]{2}{*}{ Parameters } & \multicolumn{3}{|c|}{ Feteasca Neagra } & \multicolumn{3}{|c|}{ Cabernet Sauvignon } \\
\hline & Control & $\begin{array}{c}\text { Cluster } \\
\text { thinning 30\% }\end{array}$ & significance & Control & $\begin{array}{c}\text { Cluster } \\
\text { thinning } \\
30 \%\end{array}$ & significance \\
\hline \multicolumn{7}{|c|}{ Grape parameters and yield at harvest } \\
\hline Mass of the grape (g) & $220 \pm 14.4$ & $243 \pm 14.5$ & ns & $180 \pm 15.5$ & $196 \pm 11.3$ & ns \\
\hline Berries no & $160 \pm 4.2$ & $165 \pm 3.8$ & ns & $171 \pm 7.3$ & $177 \pm 3.5$ & ns \\
\hline Rachis mass (g) & $5.25 \pm 1.1$ & $5.97 \pm 1.2$ & ns & $4.41 \pm 0.4$ & $4.89 \pm 1.1$ & ns \\
\hline Berry mass (g) & $1.38 \pm 0.3$ & $1.47 \pm 0.5$ & ns & $1.06 \pm 0.1$ & $2.22 \pm 0.7$ & ns \\
\hline Grape yield (kg/vine) & $2.06 \pm 0.5$ & $1.57 \pm 0.6$ & ns & $2.22 \pm 0.7$ & $1.67 \pm 0.5$ & ns \\
\hline \multicolumn{7}{|c|}{ Grapes indices } \\
\hline The grape structure index & $43.6 \pm 8.2$ & $41.9 \pm 5.9$ & ns & $44.1 \pm 7.6$ & $43.0 \pm 0.1$ & ns \\
\hline Berries index & $70.8 \pm 8.4$ & $66.5 \pm 8.2$ & ns & $91.8 \pm 6.8$ & $88.0 \pm 6.3$ & ns \\
\hline $\begin{array}{l}\text { The berry composition } \\
\text { index }\end{array}$ & $5.0 \pm 1.5$ & $4.3 \pm 1.2$ & ns & $3.6 \pm 0.4$ & $3.3 \pm 1.1$ & ns \\
\hline Yield index & $2.6 \pm 0.4$ & $2.2 \pm 0.3$ & ns & $2.2 \pm 0.8$ & $1.9 \pm 0.6$ & ns \\
\hline \multicolumn{7}{|c|}{ Berry structure elements and must yield } \\
\hline \%grape skin & $12.6 \pm 1.6$ & $14.2 \pm 1.7$ & ns & $16.6 \pm 2.0$ & $18.3 \pm 2.3$ & ns \\
\hline \%seeds & $4.1 \pm 0.6$ & $4.8 \pm 0.6$ & ns & $5.2 \pm 0.4$ & $5.4 \pm 0.5$ & ns \\
\hline \%pulp & $83.3 \pm 12.9$ & $81.0 \pm 12.4$ & ns & $81.0 \pm 13.4$ & $78 \pm 13.2$ & ns \\
\hline Must yield & $72.0 \pm 10.9$ & $69 \pm 11.3$ & ns & $69.0 \pm 11.8$ & $65.2 \pm 11.9$ & ns \\
\hline FS/FL & $0.200 \pm 0.02$ & $0.235 \pm 0.03$ & ns & $0.278 \pm 0.01$ & $0.308 \pm 0.03$ & ns \\
\hline
\end{tabular}

sugars. Potential phenolic and anthocyanin content determined by total polyphenol index (Fig. 1c) was also influenced by the $30 \%$ reduction of the grape clusters per vine, the increase (in the range of $15.6-16.8 \%$ ) being significant in both cases. The average weight of grapes is an important parameter, being one of the determining factors for the yield. The graph shown in Fig. 1d confirms that as far as the average weight of grapes is concerned the differences are significant for the cases in which thinning was applied.

In the study of grape parameters (Tab. 1) the determinations were made on average samples obtained from a small grape, a medium and a large grape for each variant. With these a series of technological indices were calculated too. All indices increased as a result of the application of clusters thinning operation, except for the number of berries per cluster. Berries mass showed an increase where cluster thinning was applied, by $10.4 \%$ for Feteasca Neagra and 8.8\% Cabernet Sauvignon variety, respectively but increases are not statistically significant.
Based on the determined grape parameters some indices were calculated: the grape structure index, berries index, the berry composition index and yield index, all presented in Tab.1. These indices are complemented by other parameters such as the sugar content of must and total acidity.

The grape structure index presented normal values, with significant variations between the studied variants, the berry indices values were reduced in the case of cluster thinning; significant differences were primarily determined by the biological potential of varieties, higher values being recorded in the case of Cabernet Sauvignon variety that has small grape berries than Feteasca Neagra. Reduction of clusters per vine resulted in a decrease of the berries index, due to the larger berry mass. Generally, with the exception of berry indices, all the other experimentally determined indices show lower values in the absence of grape thinning operation. The parameter values that characterize the berry structure and the skin grape percentages are lower in Feteasca Neagra as compared to Cabernet Sauvignon, these differences being due to the biological potential of 
Tab. 2. The physico-chemical composition of wines

\begin{tabular}{|c|c|c|c|c|c|c|}
\hline \multirow[b]{2}{*}{ Parameter } & \multicolumn{3}{|c|}{ Feteasca Neagra } & \multicolumn{3}{|c|}{ Cabernet Sauvignon } \\
\hline & Control & $\begin{array}{l}\text { Cluster thinning } \\
30 \% \\
\end{array}$ & significance & Control & $\begin{array}{l}\text { Cluster thinning } \\
30 \% \\
\end{array}$ & significance \\
\hline \multicolumn{7}{|c|}{ General Composition } \\
\hline $\begin{array}{c}\text { Alcohol } \\
\text { concentration (\%vol) }\end{array}$ & $12.8 \pm 0.2$ & $13.4 \pm 0.3$ & $*$ & $12.2 \pm 0.1$ & $13.0 \pm 0.2$ & $*$ \\
\hline $\begin{array}{l}\text { Reduced sugar } \\
\text { (g/10) }\end{array}$ & $2.5 \pm 0.4$ & $2.7 \pm 0.5$ & ns & $2.1 \pm 0.3$ & $2.5 \pm 0.3$ & ns \\
\hline PAT (\%vol) & $12.94 \pm 0.3$ & $13.58 \pm 0.4$ & ns & $12.28 \pm 0.2$ & $13.09 \pm 0.2$ & ns \\
\hline $\begin{array}{c}\text { Total acidity } \\
\text { (g/l tartric acid) }\end{array}$ & $6.33 \pm 0.2$ & $5.77 \pm 0.4$ & ns & $7.01 \pm 0.1$ & $6.80 \pm 0.3$ & ns \\
\hline $\begin{array}{l}\text { Volatile acidity } \\
\text { (g/l acetic acid) }\end{array}$ & $0.31 \pm 0.05$ & $0.34 \pm 0.06$ & ns & $0.41 \pm 0.03$ & $0.35 \pm 0.04$ & ns \\
\hline $\begin{array}{l}\text { Total dry extract } \\
(\mathrm{g} / \mathrm{l})\end{array}$ & $26.6 \pm 1.2$ & $27.2 \pm 2.3$ & ns & $27.4 \pm 1.6$ & $28.1 \pm 1.8$ & ns \\
\hline $\begin{array}{l}\text { Non-reducing extract } \\
(\mathrm{g} / \mathrm{l})\end{array}$ & $24.1 \pm 1.3$ & $24.6 \pm 1.5$ & ns & $25.3 \pm 1.8$ & $25.6 \pm 1.6$ & ns \\
\hline \multicolumn{7}{|c|}{ Phenolic Composition } \\
\hline $\begin{array}{l}\text { Total polyphenols } \\
\text { (mgGAE/l) }\end{array}$ & $1071 \pm 12.6$ & $1236 \pm 23.3$ & $* * *$ & $1297 \pm 16.5$ & $1732 \pm 18.3$ & $* * *$ \\
\hline $\begin{array}{l}\text { Anthocyanins } \\
(\mathrm{mg} / \mathrm{l})\end{array}$ & $409 \pm 10.4$ & $531 \pm 15.2$ & $* * *$ & $567 \pm 14.3$ & $702 \pm 13.6$ & $* * *$ \\
\hline \multicolumn{7}{|c|}{ Color } \\
\hline Coulour intensity & $9.3 \pm 2.3$ & $10.6 \pm 2.4$ & $*$ & $9.5 \pm 2.2$ & $10.7 \pm 2.4$ & $*$ \\
\hline Hue & $0.53 \pm 0.05$ & $0.52 \pm 0.06$ & ns & $0.54 \pm 0.06$ & $0.50 \pm 0.05$ & ns \\
\hline $\mathrm{dA}$ & $65.6 \pm 5.3$ & $66.1 \pm 5.7$ & ns & $65.6 \pm 6.4$ & $67.5 \pm 6.3$ & ns \\
\hline $\mathrm{d} 420 \%$ & $31.6 \pm 4.2$ & $30.7 \pm 4.2$ & $*$ & $32.3 \pm 4.0$ & $30.6 \pm 4.2$ & $*$ \\
\hline $\mathrm{d} 520 \%$ & $59.3 \pm 5.2$ & $60.1 \pm 5.1$ & $*$ & $59.4 \pm 5,0$ & $60.7 \pm 5.6$ & $*$ \\
\hline $\mathrm{d} 620 \%$ & $9.0 \pm 1.7$ & $9.2 \pm 1.8$ & ns & $8.3 \pm 1.7$ & $8.7 \pm 1.6$ & ns \\
\hline
\end{tabular}

varieties. In the case of seeds, the values are higher than the minimum limit of $3 \%$ in both varieties, with Cabernet having higher values than Feteasca Neagra, explaining the higher content of harsh tannins in the former. The cluster thinning had, however, no significant influence on \% of seeds in any of the two varieties. Regarding the amount of pulp, which exceed the minimum limit values expressed as a percentage of $75 \%$ (the values being between 78.0 to $83.3 \%$ ) the differences were insignificant among the studied variants. Must yield was also slightly reduced when the cluster thinning operation was applied.

The harvest of grapes grown organically in 2013, in the viticultural center Murfatlar was of good quality, both varieties attaining the specific parameters required by regulations for controlled origin wine production.

Statistically analyzing pairs the influence of the cluster thinning per vine on the physicochemical composition of the wines studied we observed (Tab. 2) that significant differences were recorded for a number of important parameters for wine composition such as alcohol concentration, total polyphenols and anthocyanins content, similar difference were reported also in literature (Jackson et al., 1993; Bubola et al., 2011). In terms of influence on color parameters of wines, only significant differences were observed for colour intensity, the yellow and red contribution.

In tab 3 are presented correlations between the most representative grape and wine parameters which were significantly influenced by thinning 
Tab. 3. Correlation matrix Pearson, Feteasca Neagra

\begin{tabular}{|c|c|c|c|c|c|c|c|c|c|}
\hline \multirow{2}{*}{\multicolumn{2}{|c|}{ Variables }} & \multicolumn{4}{|c|}{ Grapes } & \multicolumn{4}{|c|}{ Wines } \\
\hline & & Sugar & $\begin{array}{c}\text { Weight } 100 \\
\text { berries }\end{array}$ & Anthocyanins & IPT & Alcohol & $\begin{array}{c}\text { Total } \\
\text { polyphenols }\end{array}$ & Anthocyanir & d520\% \\
\hline \multirow{4}{*}{ Grapes } & Sugar & 1 & 0.997 & 0.934 & 0.896 & 0.996 & 0.931 & 0.929 & 0.993 \\
\hline & $\begin{array}{c}\text { Weight } 100 \\
\text { berries }\end{array}$ & 0.997 & 1 & 0.911 & 0.919 & 1.000 & 0.911 & 0.908 & 0.993 \\
\hline & Anthocyanins & 0.934 & 0.911 & 1 & 0.678 & 0.910 & 0.998 & 0.999 & 0.889 \\
\hline & IPT & 0.896 & 0.919 & 0.678 & 1 & 0.917 & 0.675 & 0.669 & 0.937 \\
\hline \multirow{4}{*}{ Wines } & Alcohol & 0.996 & 1.000 & 0.910 & 0.917 & 1 & 0.911 & 0.907 & 0.991 \\
\hline & $\begin{array}{c}\text { Total } \\
\text { polyphenols }\end{array}$ & 0.931 & 0.911 & 0.998 & 0.675 & 0.911 & 1 & 1.000 & 0.883 \\
\hline & Anthocyans & 0.929 & 0.908 & 0.999 & 0.669 & 0.907 & 1.000 & 1 & 0.881 \\
\hline & $\mathrm{d} 520 \%$ & 0.993 & 0.993 & 0.889 & 0.937 & 0.991 & 0.883 & 0.881 & 1 \\
\hline
\end{tabular}

operations. Pearson correlation coefficient is sensitive only to a linear relationship between two variables, but give a good idea regarding the main dependent parameters.

\section{CONCLUSION}

The application of $30 \%$ cluster thinning operation led to higher quality grapes in both varieties, especially as far as the sugar content was concerned, which increased by 2.7 to $5.4 \%$, and also by the anthocyanins with increased values ranging between 15.6 to $16.8 \%$, which led to an increase in wine quality as regards color and phenolic composition. Technological indices varied within a small interval, the low yields being easily compensated by the increase in grape quality, leading to full-bodied wines with good extractivity, rich in phenolic compounds. These types of wines are appreciated by general consumers, also appealing to those looking for natural products rich in bioactive substances with a good effect on health. In practice, the application of this operation is recommended when the numbers of grapes are excessive or a better grape and wine quality is desired.

\section{REFERENCES}

1. Antoce A, Cazacu S, Nămoloşanu I, Ivaşcu M, Dumitru D, Voiculescu I, Ficiu L, Dumitrascu L, Damian D (2008) Guide to organic viticulture - application of organic viticulture and methodologies in Romania, Ed. Alpha MDN.

2. Bubola M, Peršurić D, Ganić K K (2011). Impact of cluster thinning on productive characteristics and wine phenolic composition of cv. Merlot. J. Food Agric. Environ., 9, 36-39.
3. Council Regulation (EEC) $N^{\circ} 834 / 2007$ of 28 June 2007 on organic production and labeling of organic products and repealing Regulation (EEC) No 2092/91.

4. Demir K (2011). Influences of pre- and post-veraison cluster thinning treatments on grape composition variables and monoterpene levels of Vitis vinifera L. cv. Sauvignon Blanc. J. Food Agric. Environ., 9, 22-26.

5. Filippetti I, Ramazzotti S, Centinari M, Bucchetti B, Intrieri $C$ (2007). Effects of cluster thinning on grape composition: Preliminary experiences on 'Sangiovese' grapevines. Acta Hortic 754, 227- 234.

6. Glories Y, (1984). La couler des vins rouges. Connaisance Vigne Vin, 18(4), 253-271.

7. Guidoni S, Ferrandino A, Novello V (2008). Effects of seasonal and agronomical practices on skin anthocyanin profile of Nebbiolo grapes. Am. J. Enol. Vitic., 59, 22-29.

8. Jackson DI, Lombard PB (1993). Environmental and management practices affecting grape composition and wine quality: A review., Am. J. Enol. Vitic., 44, 409-430.

9. Merchán PJAM, Fischer G, Cely PAS, López HEB, Galvis JA (2011). Effects of leaf removal and cluster thinning on yield and quality of grapes (Vitis vinifera L., Riesling $\times$ Silvaner) in Corrales, Boyaca (Colombia). Agronomía Colombiana 29(1), 35-42.

10. Ranca A, Antoce A, Artem V, Petrescu A, Stanciu C, ColicSova C (2013). Principles of organic viticulture applied in Murfatlar vineyard, Romania, Fourth International Scientific Simposium „Agrosim 2013” 3-6 oct 2013, Jahorina, Bosnia and Herzegovina.

11. Reynolds A, Price S, Wardle D, Watson B (1994). Fruit Environment and Crop Level Effects on Pinot noir Vine Performance and Fruit Composition in the British Columbia. Am. J. Enol. Vitic 45, 452-459.

12. Ribereau - Gayon (1976). Traite d'oenologie -Sciences et techniques du vin, vol 1-Dosage des anthocyanes dans le vins rouge, Paris, 494-499.

13. Singleton VL, Rossi JA jr. (1965). Colorimetry of total phenolics withphosphomolybdic - phosphotungsticacid reagents, Amer J. Enol. Viticult 16, 144-158.

14. Valdes ME, Moreno D, Gamero E, Uriarte D, Prieto MH, Manzano R, Picon J, Intrigliolo DS (2009). Effects of cluster thinning and irrigation amount on water relations, growth, yield and fruit and wine composition of Tempranillo grapes in Extremadura (Spain). J. Int. Sci. Vigne Vin, 43, 67-76.

15. http://www.vignevin-sudouest.com/services-professionnels/methode-analyse/Potentiel-polyphenoliquevendange.php (Méthode ITV) (feb 2012). 